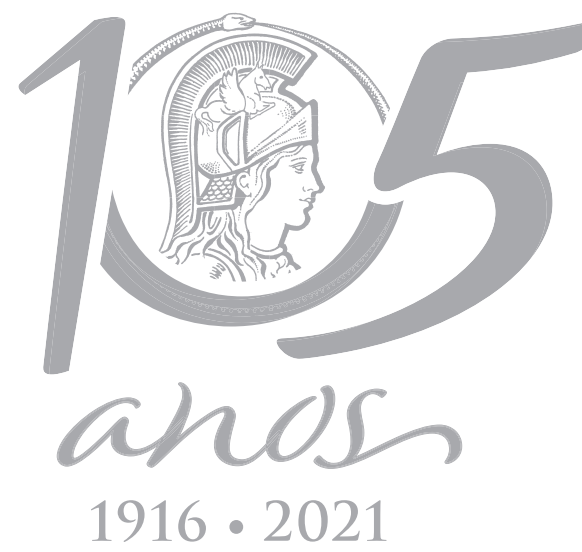

\title{
PALEONTOLOGY
}

\section{A new genus of fossil frog (Anura) from lower Cretaceous deposits in South America}

\author{
PEDRO HENRIQUE A.G. MOURA, FABIANA R. COSTA, LUIZ E. ANELLI \& \\ IVAN NUNES
}

\begin{abstract}
The frog clade Neobatrachia or "advanced frogs" represents more than $95 \%$ of the diversity within Anura. The neobatrachian fossil record is incomplete due to the small size and fragile nature of their bones but provides some clues on the time and rate of the current diversification of modern-day amphibians. The Crato Formation (Aptian) of northeastern Brazil is known for the presence of, at least, five species of neobatrachian fossils. Herein, we describe a well-preserved fossil that represents a new neobatrachian taxon from the Crato Formation (Cretaceous) in the Araripe Basin, northeastern Brazil, and perform phylogenetic analysis to assess its higher-level relationships. The new specimen is an almost complete and articulated skeleton with soft tissue preservation. Phylogenetic analysis recovered the specimen nested in the clade Hyloidea and our results highlight the remarkable value of the Crato Formation as a Laggerstätte.
\end{abstract}

Key words: Amphibia, fossil anuran, Cretaceous, Primaevorana cratensis.

\section{INTRODUCTION}

Among anurans, the clade Acosmanura Savage 1973 comprises Anomocoela Nicholls 1916 (= Pelobatoidea of some authors; e.g. Chen et al. 2016), whose members were formerly considered as part of the "middle frogs" (Mesobatrachia; Ford \& Cannatella 1993), and Neobatrachia Reig 1958 or "advanced frogs" (Frost et al. 2006). Representing more than $95 \%$ of the diversity within Anura (Frost et al. 2006, Frost 2020), Neobatrachia presents a cosmopolitan distribution, except for extreme northern latitudes, Antarctica, and most oceanic islands (Frost et al. 2006, Frost 2020).

The neobatrachian fossil record, particularly in the Mesozoic, is of incomplete nature (Agnolin et al. 2020). This can be, at least partially, due to the small size and fragile nature of their bones, which hamper the potential of fossilization (Moura \& Barreto 2006, Lynch 1973, Leite et al.
2011). Such incompleteness provides few clues on the time and rate of the current diversification of modern-day amphibians (Roelants et al. 2007, Baéz et al. 2009), but highlights the importance that new fossil findings can have in current hypotheses about the origin and evolution of the clade (Agnolin et al. 2020).

The Crato Formation (Aptian) of northeastern Brazil is one of the most important Cretaceous deposits worldwide and has yielded many well-preserved fossil vertebrates (Martill 2007). Anurans are represented by the neobatrachian Araryphrynus placidoi (Leal \& Brito 2006), Eurycephalella alcinae (Baéz et al. 2009), Cratia gracilis (Baéz et al. 2009), Kururubatrachus gondwanicus (Agnolin et al. 2020), and the pipoid Cratopipa novaolindensis (Carvalho et al. 2019). This unit is part of the Araripe Basin, a small intracratonic basin that comprises the states of Ceará, Pernambuco, and Piauí, and whose tectonic evolution is linked to the opening of 
the South Atlantic Ocean (Medeiros et al. 2001, Baez et al. 2009). The Crato Formation itself is included in the Santana Group, representing the post-rift stage of the Araripe Basin, and is up to $100 \mathrm{~m}$ thick and consists of carbonate units, majorly composed of laminated limestones interbedded between grained siliciclastic, intercalated by sandstones and shales (Viana \& Neumann 2002). Environmentally, it has been interpreted as deposits associated with lentic environments, such as paleolakes or lagoons, (Martill 2007), and traditionally considered to present a semiarid climate with a marked dry season during deposition (Lima 1978).

Many fossils from the Crato Formation are at some extent three-dimensionally preserved and almost complete, suggesting that deposition occurred under low-energy conditions (Báez et al. 2009). Furthermore, the batrachofauna shows a high taxonomic diversity and yields some of the earliest records of neobatrachians, with no remains of this latter group being reported for other known batrachofaunas from the Lower Cretaceous (Báez et al. 2009, Agnolin et al. 2020). Herein, we describe a well-preserved fossil that represents a new neobatrachian taxon, Primaevorana cratensis gen. et sp. nov., and perform a phylogenetic analysis to assess its higher-level relationships.

\section{MATERIALS AND METHODS}

Osteological nomenclature for the description of Primaevorana cratensis followed: Gaupp (1896) for fore- and hindlimbs; Trueb (1970, 1973, 1993) for cranial and post-cranial regions; and Fabrezi (1992, 2001) for carpal and tarsal osteology. The phylogenetic relations of $P$. cratensis within Anura were accessed by using the matrix of Báez \& Gomez (2018), with the addition of the recently described Kururubatrachus godnwanicus. The inclusion of $P$. cratensis and $K$. gondwanicus in the matrix was performed using Mesquite 3.51 (Maddison \& Maddison 2018). The final matrix encompassed 73 anuran taxa, including the new species, and 143 characters.

In all analyses, Maximum Parsimony was used as the optimality criterion. This choice of optimality criterion is put forward because it minimizes the number of transformation events necessary to explain the character states of terminal taxa as hypotheses of homology (Kluge \& Grant 2006, Grant \& Kluge 2009). Analyses were performed with the software TNT v. 1.1 (Goloboff et al. 2008a). The most parsimonious trees were found using the heuristic search method, with 1000 rounds of random addition sequences retaining 10 trees per replicate, and then submitting them to a round of tree bisection and reconnection (TBR) branch swapping. The resulting trees saved in RAM were then submitted to a second round of TBR. All nodes whose minimum length was zero were collapsed.

To comprehensively test the phylogenetic position of the new fossil, we carried out unconstrained and constrained analyses (Báez et al. 2009, Baéz \& Gomez 2018). The unconstrained analyses were performed on the full matrix with multistate characters under equal weights and under implied weights with different values of the concavity constant $k(1-15,20,30)$ to improve phylogenetic analysis against homoplasy (Goloboff et al. 2008b, Baéz et al. 2009). Similarly, constrained analyses were also performed both under equal weights and implied weights using the topology of Jetz \& Pyron (2018) for Anura, with fossil taxa defined as floaters.

Clade support was estimated by calculating parsimony Jackknife absolute frequencies and Goodman-Bremer values (Goodman et al. 1982, Bremer 1988, Grant \& Kluge 2008) in TNT v. 1.1 (Goloboff et al. 2008a). Jackknife values 
were calculated using "Traditional Search" with the same parameters described above and 1000 replicates. Character states were considered synapomorphies if they optimized unambiguously since preferential selection for ACCTRAN or DELTRAN optimization is arbitrary (see Agnarsson \& Miller 2008).

Institutional abbreviations: GP/2E (Systematic Paleontology Lab, Geosciences Institute, Universidade de São Paulo, São Paulo, Brazil). The material reported here, GP/2E 9497, was seized from fossil smugglers by the Brazilian Federal Police and forwarded to the "Department of Sedimentary and Environmental Geology", Universidade de São Paulo, where it is housed. The material is preserved in a slab of the typically laminated carbonate beds of the Crato Formation. The detailed photos and measurements were taken from the specimen using a Zeiss Stemi SV11 stereomicroscope coupled with a camera (precision $0.01 \mathrm{~mm}$ ).

The electronic edition of this article conforms to the requirements of the amended International Code of Zoological Nomenclature, and hence the new names contained herein are available under that Code from the electronic edition of this article. This published work and the nomenclatural acts it contains have been registered in ZooBank, the online registration system for the ICZN. The ZooBank LSIDs (Life Science Identifiers) can be resolved and the associated information viewed through any standard web browser by appending the LSID to the prefix "http:// zoobank.org/". The LSID for this publication is: urn:Lsid:zoobank.org:pub:BB939676-79E7-4D17A2C0-8C8DBDD51A5F. No permits were required for the described study, which complied with all relevant regulations. See appropriate section of Systematic Paleontology for locality, stratigraphy, repository and specimen number.

\section{RESULTS}

\section{Systematic Paleontology}

Anura Fischer Von Waldheim 1813

Neobatrachia Reig 1958

Primaevorana cratensis gen. et sp. nov. (Figures 1, 2, 3, 4 and 5)

Etymology. The generic name is a composition of the Latin words primaevus (from primus "first" + aevum "age") and rana (frog). The specific epithet cratensis is an allusion to the Crato Formation, the geologic unit where the specimen was found.

Holotype. GP/2E-9497 (housed at Department of Sedimentary and Environmental Geology, USP, São Paulo, Brazil), an articulated and relatively complete adult specimen.

Type locality, horizon, and age. Crato Formation, Lower Cretaceous (Aptian), region of Nova Olinda, Araripe Basin, Ceará state, Northeastern Brazil. The exact locality is undetermined.

Diagnosis. Small anuran assigned to Neobatrachia by having free palatines (= neopalatines; Trueb 1993) and on inferred relationships using phenotypic data presented by Baéz \& Gomez (2018). The new species differs from pipoids in having a T-shaped parasphenoid and well-developed mentomeckelians. P. cratensis can also be distinguished from all other neobatrachians by the following combination of characters: dentate maxilla; pterygoid with a long medial ramus; clavicle curved and anteriorly concave; coracoid with glenoidal end more expanded than the sternal end.

Primaevorana cratensis can be distinguished from other Crato neobatrachians by the following combination of characters: skull longer than wide (wider than long in Eurycephalella alcinae, equal in Arariphrynus placidoi; Baez et al. 2009); orbital region posteriorly wider than anteriorly (equally wide in Cratia gracilis and Kururubatrachus 

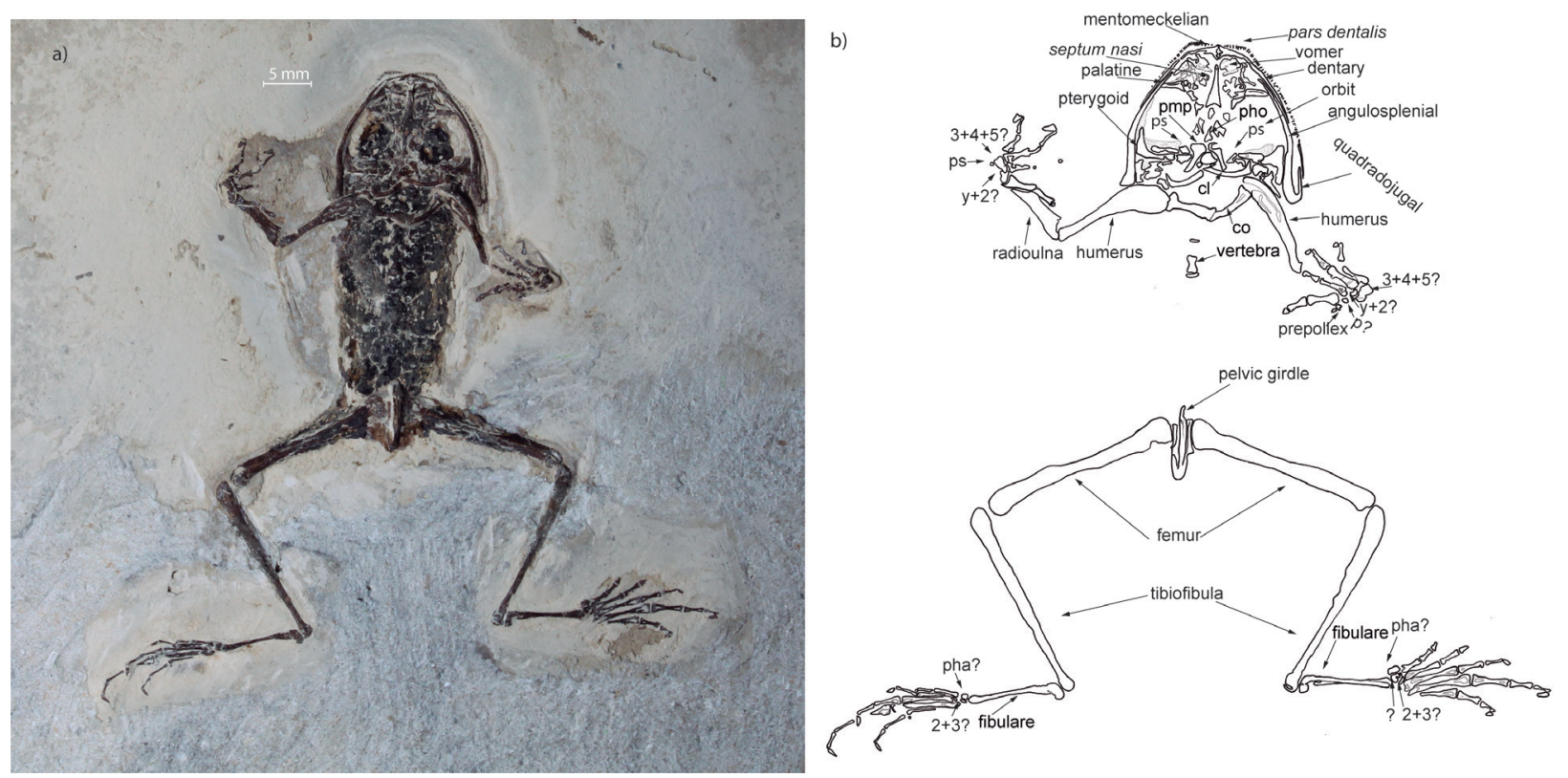

Figure 1. Primaevorana cratensis, holotype (GP/2E-9497) from Crato Formation, Lower Cretaceous (Aptian), region of Nova Olinda, Araripe Basin, Ceará state, Northeastern Brazil. a) Photograph by Luiz E. Anelli; b) Illustration of the fossil. Abbreviations: pmp: posteromedial processes of the hyoid; pho: parahyoid ossification; ps: parasphenoid; $3+4+5$ : distal carpals $3+4+5$; ps: palmar sesamoid; $y+2$ : element $y+$ distal carpal 2 ; p: proximal element of the prepollex; $2+3$ : distal tarsals $2+3$; pha: prehallux.

gondwanicus; Baez et al. 2009, Agnolin et al. 2020); robust clavicle (slender in C. gracilis; Baez et al. 2009); coracoid with an asymmetric sternal end (symmetric in C. gracilis; Baez et al. 2009); humerus not proximally expanded (expanded in K. gondwanicus; Agnolin et al. 2020); femur shorter than tibiofibula (equal lengths in $C$. gracilis; Baez et al. 2009); tibiale and fibulare lengths that are half the length of the tibiofibula (one third of the length in E. alcinae and Ar. placidoi; Baez et al. 2009); terminal phalanges without protuberances (distal protuberances present in E. alcinae and Ar. placidoi; Baez et al. 2009).

Measurements of the holotype (in milimeters; $\mathbf{D}=$ dextral; $\mathrm{S}=$ sinistral). SnoutVent Length 40.00; Head Length 15.25; Head Width 14.40; Humerus Length D 10.90, S 9.70; Forearm Length (radio-ulna) D 5.90; Thigh Length (= femur) D 17.90, S 17.60; Tibia Length D 18.20,
S 18.00; Foot Length (tarsus + toe IV) D 14.30, S 13.80.

Description. The specimen consists of a single articulated and well-preserved adult individual $(40.00 \mathrm{~mm})$. It is preserved on a limestone slab and is exposed in ventral view with a clearly visible skull (palatal region and mandible), pectoral girdle, and fore- and hindlimbs (Figure 1). Soft tissue preservation is also noticeable, especially in the orbital and abdominal regions (Figure $2 \mathrm{a}, \mathrm{d}$ ), the latter occulting most of the vertebral column which is also embedded in the rock (Figure $2 \mathrm{~d}$ ).

Cranium (Figure 2a, b, c): The skull is slightly wider than long and has large orbits. The only visible maxillary arch elements are the teeth bearing pars dentalis of the premaxillary and maxillary. These teeth are spatulate and possibly bicuspid, although this could not be verified with certainty. A quadratojugal is present and articulates with the maxillary. 

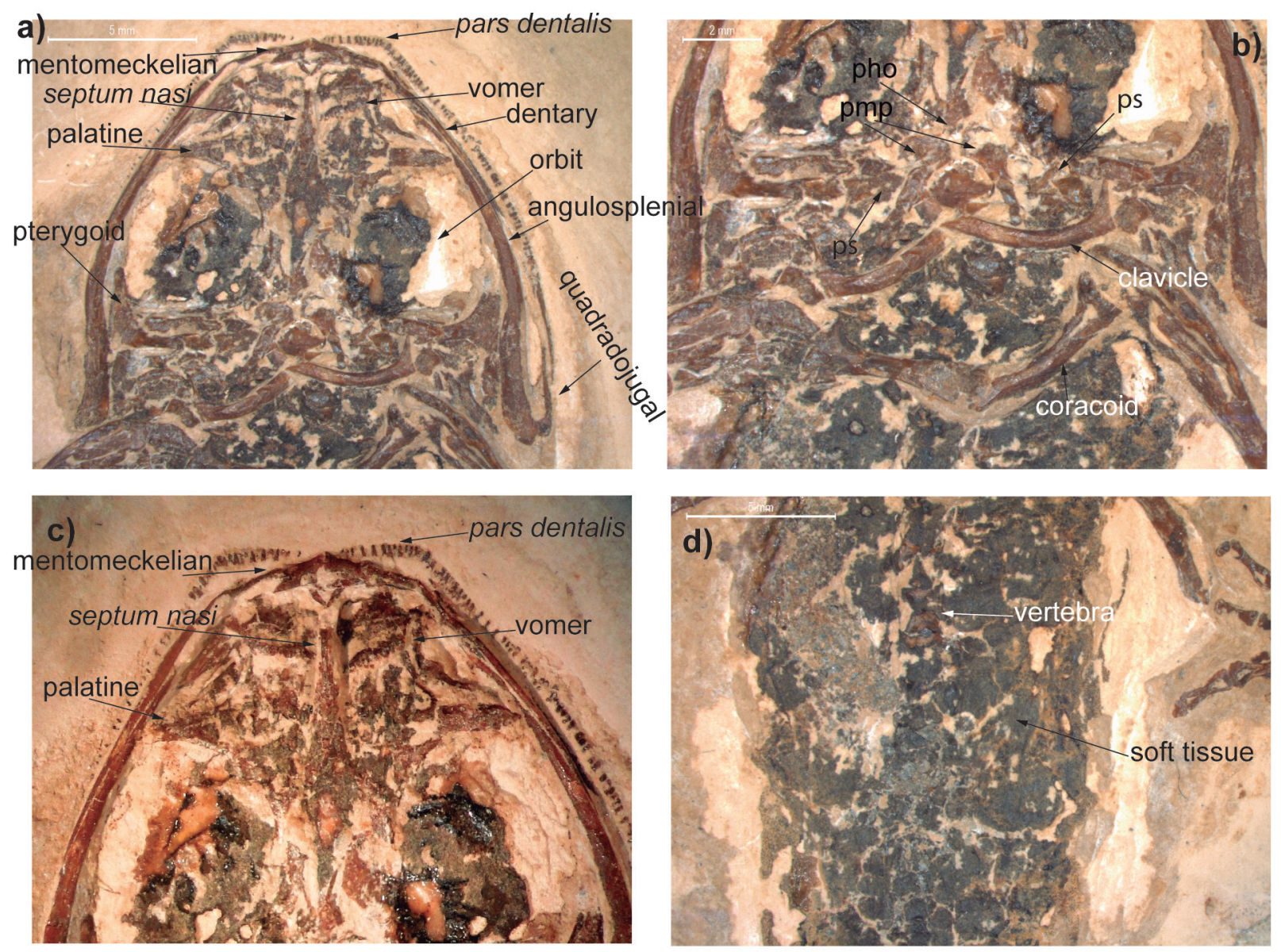

Figure 2. Primaevorana cratensis, holotype (GP/2E-9497) from Crato Formation, Lower Cretaceous (Aptian), region of Nova Olinda, Araripe Basin, Ceará state, Northeastern Brazil. a) Cranium; b) Pectoral girdle; c) Anterior portion of the cranium; d) Trunk. Photographs by Ivan Nunes. Abbreviations: pmp: posteromedial processes of the hyoid; pho: parahyoid ossification; ps: parasphenoid.

Fragments of the parasphenoid are present, some of which we identify as the alae that extended laterally and perpendicular to the cultriform process. The vomers extend posteriorly slightly less than halfway to the palatines and are teeth-bearing. Between the vomers, a bone fragment is visible that corresponds to a well-ossified portion of the septum nasi of the nasal capsule. The palatines are free, presenting a smooth transverse ridge, and extend medially until half the orbit width. Pterygoids are triradiate with all three rami (anterior, medial, and posterior) present; the anterior ramus articulates with the maxillary and the midlevel of the orbit; the medial ramus articulates with the optic capsule.

Three elements of each mandibular arch are visible: the mentomeckelian (symphysial bone), dentary, and angulosplenial (angular bone). The mentomeckelian is wide, extending laterally until $1 / 3$ the length of the orbit. The ossified posteromedial processes of the hyoid plate are visible, proximally, and distally expanded, with the proximal being wider than the distal. Evidence of parahyoid ossification present immediately anterior to the posteromedial processes. 

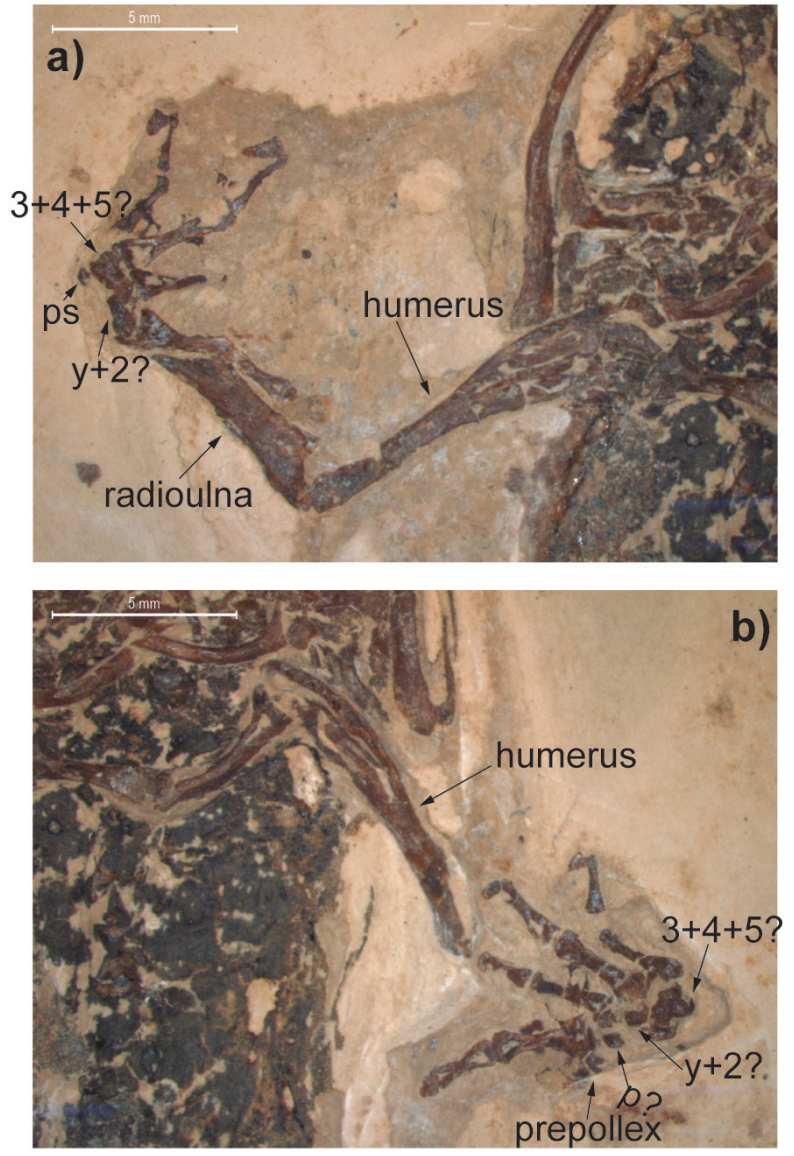

Figure 3. Primaevorana cratensis, holotype (GP/2E-9497) from Crato Formation, Lower Cretaceous (Aptian), region of Nova Olinda, Araripe Basin, Ceará state, Northeastern Brazil. a) Right forelimb; b) Left forelimb. Photographs by Ivan Nunes. Abbreviations: $3+4+5$ : distal carpals $3+4+5$; ps: palmar sesamoid; $y+2$ : element $y+$ distal carpal 2; p: proximal element of the prepollex.

Pectoral girdle (Figure 2b): Arciferal, as suggested by the clavicles that are curved, anteriorly concave, and robust. The glenoidal end is expanded. The degree of separation between the clavicles could not be observed because of dislocation. The coracoids are robust, slightly curved, and anteriorly concave, with sternal and glenoidal expansion. The glenoidal end is more expanded than the sternal end. Between the posteromedial processes of the hyoid plate, lies a discoidal bony element that probably corresponds to a fragment of the ventral surface of the skull. This fragment representing a coossified parasphenoid, prootic, and exoccipital. Other pectoral girdle elements were not identifiable.

Forelimb and manus (Figure $3 \mathrm{a}, \mathrm{b}$ ): The head of the humerus (caput humeri) is well developed, larger in diameter than the distal width of the bone at the distal portion. The shaft of the humerus straight in the distal half. Welldeveloped crista ventralis, high and extending over the proximal half of the bone. Shallow and straight crista medialis. The epicondilus ulnaris, lateralis and the eminentia capita could not be observed. The radioulna is robust. The sulcus intermedius and the olecranon process could not be observed. The capitulum process is well developed.

The carpal elements on both hands are difficult to identify because of possible dislocations due to the fossil's preservation. Therefore, we present a tentative assignment of elements. On the left manus (Figure 3b), distal carpal 3+4+5, element y-distal carpal 2 , and a proximal prepollical element are visualized, along with a prepollex composed of at least two elements. On the right manus (Figure 3a), distal carpal 3+4+5, element y-distal carpal 2 , can be visualized, with a smaller separate element that could represent a palmar sesamoid. The metacarpals are slightly more elongated than the antepenultimate phalanges, with their lengths (in ascending order) being: II $<\mathrm{V}<\mathrm{III}=\mathrm{IV}$. The phalangeal formula is 2-2-3-3. The length of the distal phalanges could not be determined. Carpal torsion is present.

Pelvic girdle (Figure 4a, b): The only visible elements were those composing the posterior portion of the pelvic girdle, where the ilium and ischium articulate; hence, the ilial shafts and other parts extending anteriorly were not apparent. The shape of the acetabulum could not be determined, since only the ventral half 

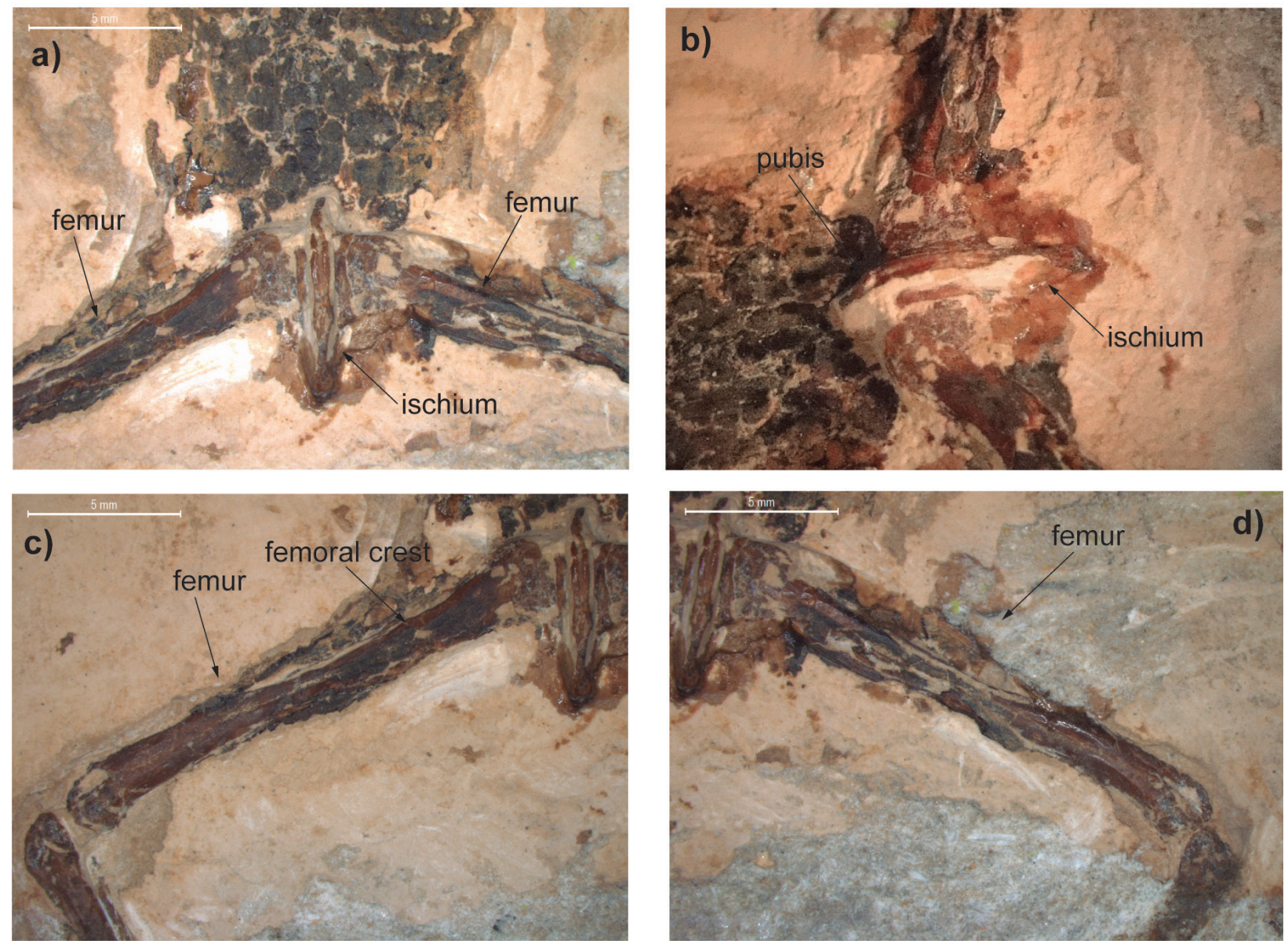

Figure 4. Primaevorana cratensis, holotype (GP/2E-9497) from Crato Formation, Lower Cretaceous (Aptian), region of Nova Olinda, Araripe Basin, Ceará state, Northeastern Brazil. a) Pelvic girdle; b) Detail view of pelvic girdle; c) Right hindlimb; d) Left hindlimb. Photographs by Ivan Nunes.

is visible. The ischium is robust and long, with its length being larger than the diameter of the acetabulum.

Hindlimb and pes (Figures 4c, d, and 5): The hind limb of the specimen is long. The weakly sigmoid femur is only fractionally shorter than the tibiofibula and presents a crest. The tibiale and fibulare (fused proximally and distally) are only about half the length of the tibiofibula. The proximal end of the femur is expanded, with the distal end being narrower than the proximal. The distal end of the fibulare is wider than the proximal end. Because of the position in which the specimen fossilized, most of the tibiale became occluded by the fibulare.
Similarly, as for the carpus, the identification of the tarsal elements is difficult and is only tentative. On the right tarsus (Figure $5 \mathrm{~d}$ ), two elements can be discriminated, that possibly corresponds with distal tarsal $2+3$ and a prehallical element. On the left tarsus (Figure 5c), at least three elements can be discriminated, two of which we propose corresponds with distal tarsal $2+3$ and a prehallical element. The third element is a large bony fragment that was not identifiable. The lengths of the metatarsals are I $<$ II $<$ V $<$ III $<$ IV; the longest metatarsals are smaller than the tibiofibulares. The phalangeal formula is 2-2-3-4-3, and the toe lengths are $1<$ $\mathrm{II}<\mathrm{V}=\mathrm{II} \mid<\mathrm{IV}$. The terminal phalanges are short, robust, and terminally acuminate. 

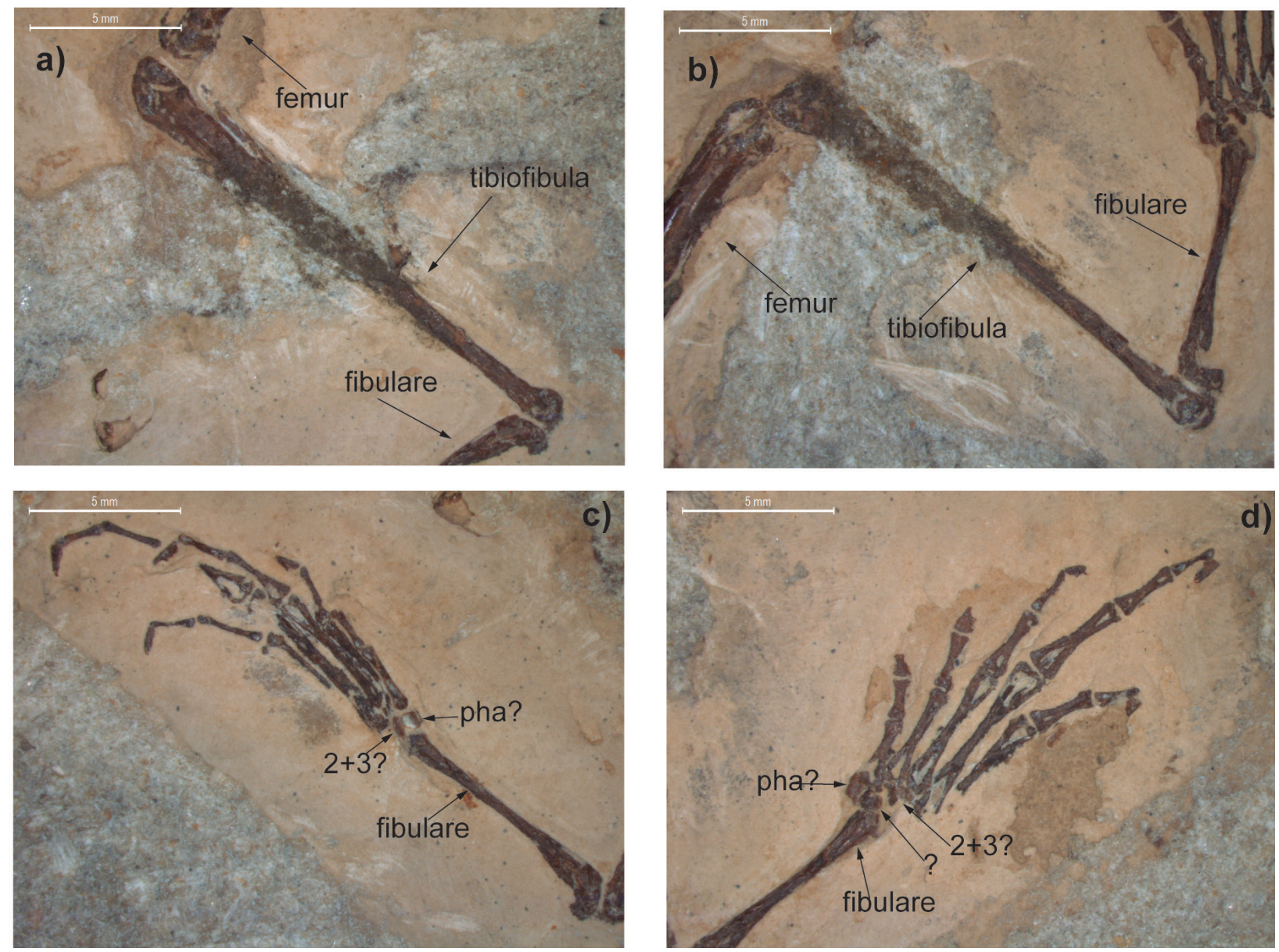

Figure 5. Primaevorana cratensis, holotype (GP/2E-9497) from Crato Formation, Lower Cretaceous (Aptian), region of Nova Olinda, Araripe Basin, Ceará state, Northeastern Brazil. a) Right hindlimb; b) Left Hindlimb; c) Right pes; d) Left pes. Photographs by Ivan Nunes. Abbreviations: 2+3: distal tarsals 2+3; pha: prehallux.

\section{Phylogenetic relationships}

The character states for Primaevorana cratensis gen. et sp. nov. and Kururubatrachus gondwanicus were coded in the data matrix as

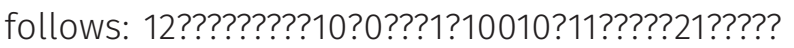
??10????????1?010??????????1????1?????????????????

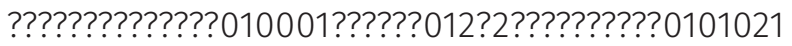
??00? and 20??20????????????????????1????????3???

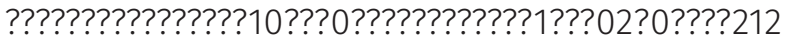

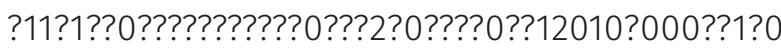
$1111 ? 00 ?$.

The unconstrained heuristic search under equal weights resulted in the six most parsimonious trees with 1335 steps, Consistency Index (Ci) of 17, Retention Index (Ri) of 56. The strict consensus topology is almost identical to that of Baez \& Gomez (2018: Figure 9), with the Costata as the sister clade of a trichotomy that contains Anomocoela, Heleophryne natalensis, and a clade that comprises all remaining neobatrachians. Nested within this latter clade, Primaevorana cratensis was recovered as the sister of Strabomantis ingeri, with which it composes the sister group of a clade that includes Hemiphractus fasciatus + (Ceratobatrachus guentheri + ( Pyxicephalus adspersus + Thaumastosaurus gezei)). The more inclusive clade comprises several hyperossified hyloid and ranoid taxa, a grouping that is highly divergent from previous phylogenies based on 
a)

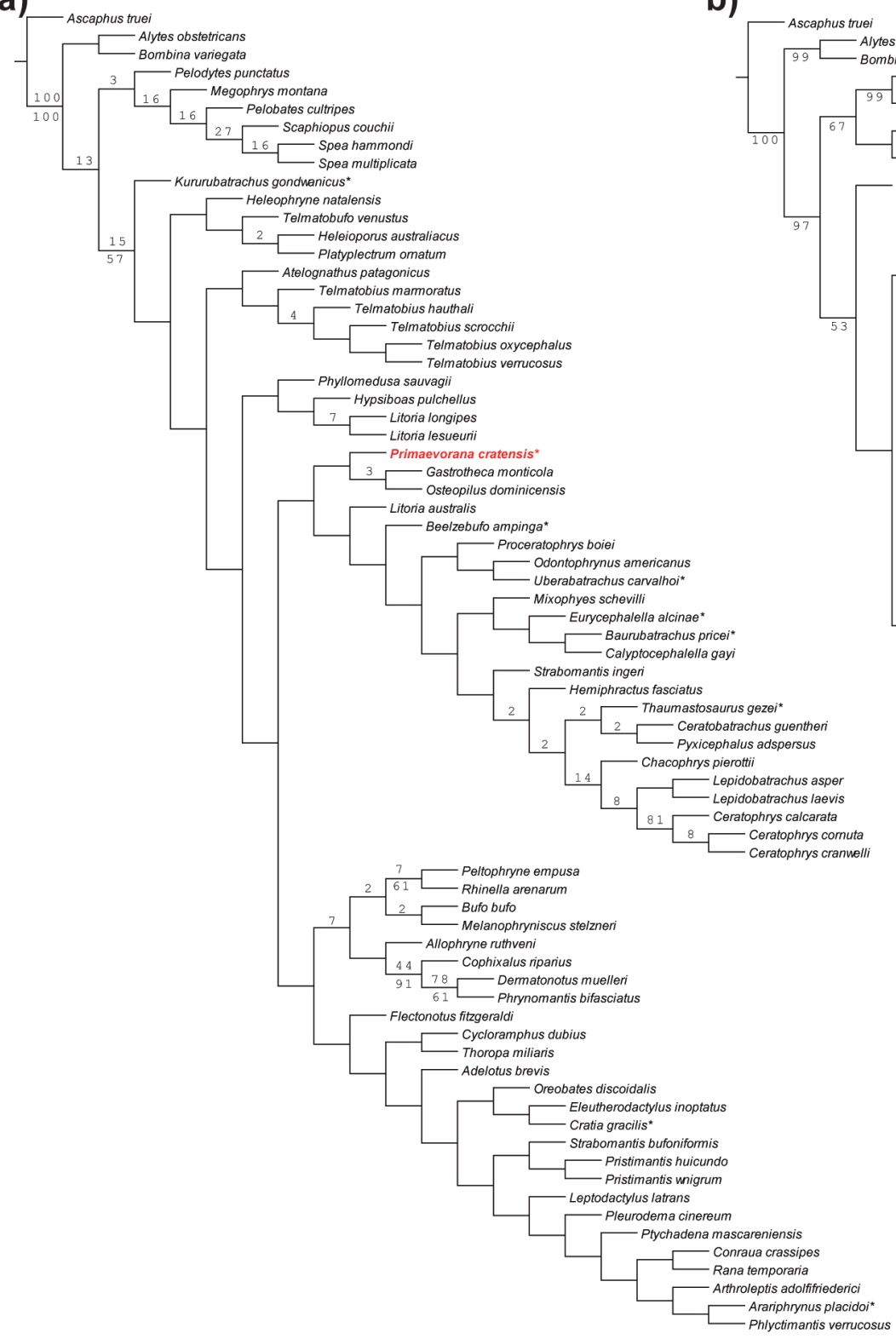

b)

\section{)}

Figure 6. Phylogenetic trees obtained from the maximum parsimony analyses using the heuristic search of TNT v. 1.1, under implied weights. a) Unconstrained analysis with $k=7 ; b$ ) Constrained analysis with $k=15$. The fossil taxa are indicated with an asterisk. The new species is highlighted in bold. Numbers above nodes are relative Goodman-Bremer support values; numbers below nodes are Jackknife values. Only Jackknife values above $50 \%$ are displayed.

molecular or morphological characters (e.g. Frost et al. 2006, Baez et al. 2009, Pyron 2014, Jetz \& Pyron 2018). This placement of P. cratensis is supported by a homoplastic character (Ch. 68.1: Posteromedial process of the hyoid with ossification that reaches the hyoid plate).
Under implied weights, the unconstrained search resulted in only one tree with 1349 steps, $\mathrm{Ci}=17$ and $\mathrm{Ri}=55$ (Figure 6a). In this topology, Neobatrachia is monophyletic with Kururubatrachus gondwanicus as the sister of all remaining Neobatrachia. Primaevorana cratensis 
is grouped as the sister taxon of Gastrotheca monticola + Osteopilus dominicensis. The immediately more inclusive clade also includes several hyperossified hyloid and ranoid taxa, resembling the unconstrained equal weights topology. This grouping of P. cratensis also is supported by a homoplastic character (Ch. 12.1: Anterior ramus of pterygoid not reaching planum antorbitale).

Using the topology of Jetz \& Pyron (2018) as a constraint, the heuristic search under equal weights found 28 most parsimonious trees with 1526 steps, $\mathrm{Ci}=15$ and $\mathrm{Ri}=48$. The strict consensus topology recovers a highly unresolved Neobatrachia, where seven of the nine fossil taxa, including the new fossil, are of uncertain placement in a large polytomy. With implied weights $(k=15)$, the analysis resulted in one tree, with 1532 steps, $\mathrm{Ci}=15$ and $\mathrm{Ri}=$ 48 (Figure 6b). In this tree, Neobatrachia is monophyletic and Heleophryne natalensis is the sister taxon of all Neobatrachia. Among the remaining neobatrachians, Primaevorana cratensis is nested within Hyloidea and is sister to a clade that includes (Gastrotheca monticola + (Flectonotus fitzgeraldi + Hemiphractus fasciatus)) + Eleutherodactylus inoptatus + (Strabomantis + (Oreobates discoidalis + (Pristimantis huicundo + (Arariphrynus placidoi + Pristimantis wnigrum). In this phylogeny, the placement of $P$. cratensis is supported by one homoplastic character: Anterior ramus of pterygoid not reaching planum antorbitale (Ch. 12.1).

\section{DISCUSSION}

Herein we described Primaevorana cratensis based on a single fossil specimen with remarkable preservation, exhibiting an almost complete articulated skeleton and noticeable soft tissue preservation on the orbital and abdominal regions. Soft tissue is distinguishable from the matrix and bone tissue by the darker coloration and different textures (Figure 2a, d). Fossilized soft tissue from the Araripe Basin was previously reported, for example, for fossil fishes (Martill 1988), pterosaurs (Kellner 1994, 1996a), and theropods (Kellner 1996b), possibly associated with phosphatization (Martill 1989). Asforanurans from the same region, such a record was limited mostly to impressions on the rocky matrix (Baéz et al. 2009), until the description of Cratopipa novaolindensis (Carvalho et al. 2019). Similarly, as for C. novaolindensis, the characteristics of the new fossil's preservation are consistent with previous studies that demonstrated that frogs in microbial mats presented a significant delay in decay of soft tissues, with the body remaining articulated (Iniesto et al. 2017, Carvalho et al. 2019). This makes $P$. cratensis the second register of its kind for this region, highlighting the need for future studies that could contribute to a better understanding of the bioecology of these animals.

To assess the phylogenetic position of Primaevorana cratensis, we included the new fossil in the morphological matrix of Baéz \& Gomez (2018) alongside all other Crato neobatrachians (Baéz et al. 2009, Agnolin et al. 2020). Parsimony analyses recovered $P$. cratensis as a member of Neobatrachia, although internal relations in this clade had overall low support. Despite being a well-preserved specimen, some phylogenetically informative characters, especially those related to the vertebral column (e.g. Reig 1958, Lynch 1971, 1973, Baéz et al. 2009, Baéz \& Gomez 2018) could not be scored because they are covered by the sedimentary matrix. Nevertheless, $P$. cratensis can be confidently assigned to this group by the presence of free palatines (neopalatines of Trueb 1993) and, putatively, the presence of 
fused distal tarsals $2+3$, which are diagnostic features of Neobatrachia as a whole (Reig 1958, Ford \& Cannatella 1993, Báez et al. 2009).

Regarding the inner relations of Neobatrachia, most clades do not present osteological synapomorphies (Baéz et al. 2009). Furthermore, the high degree of homoplasy in Anura (Baéz \& Gomez 2018) and the limited nature of fossil information contribute to the uncertain phylogenetic positioning of fossil taxa. To attenuate these shortcomings, we performed further parsimony analyses with weighting against homoplasy (Farris 1969, Goloboff 2003, Baéz \& Gomez 2018) and using a recent topology resulting from molecular analyses (Jetz \& Pyron 2018) as a scaffold to explore the position of the new fossil. In this sense, we sought to apply a framework that was in line with the requirement of total evidence (Kluge 1989).

These analyses produced phylogenies with overall low support, with the most consistent results (when compared with recent relationship hypotheses for Anura) exhibited by the constrained analysis under implied weights (Figure 6b). In this topology, Primaevorana cratensis is placed among hyloid anurans, with the anterior ramus of pterygoid not reaching planum antorbitale (Ch. 12.1) as an ambiguous synapomorphy. Among characteristics associated with Hyloidea are those related to the vertebral column (Lynch 1971, 1973, Báez \& Peri 1989), as well as an ossified crista parotica of the skull and the presence of the tectum parietale (Baéz \& Gomez 2018). Because of the position and embedding in the sedimentary matrix, these characters could not be observed in our specimen. However, it is reasonable to assume that $P$. cratensis probably presents at least an ossified crista parotica, given the degree of cranial ossification observed.

It is important to note that the dataset put forward by Baéz \& Gomez (2018) comprises the most comprehensive osteological character matrix available, but still no unambiguous synapomorphies for neobatrachian clades, such as Nobleobatrachia, were retrieved (Baéz \& Gomez 2018). This lack of knowledge on synapomorphies or combinations of diagnostic characters reflects the fact that there has been little attempt to explore the comparative anatomy of frogs on the scale of all neobatrachian lineages considering modern phylogenetic hypotheses. An example of a significant contribution regarding myology is the recent work of Blotto et al. (2020), and similar enterprises focusing on osteology would provide important subsidies for further investigations of fossil and extant taxa alike.

The description presented herein adds to the already diverse Cretaceous batrachofauna of the Crato basin in northeastern Brazil (Baéz et al. 2009, Agnolin et al. 2020). These include the pipoid Cratopipa (Carvalho et al. 2019) and the neobatrachians Arariphrynus, Cratia, Eurycephalella, and Kururubatrachus (Baéz et al. 2009, Agnolin et al. 2020). Aside from the hyloid affinities of Primaevorana, our analyses confirmed the hyloid nesting of Eurycephalella (Baéz et al. 2009, Baéz \& Gomez 2018) and Arariphrynus (Baéz et al. 2009). The latter was previously recovered as a ranoid (Laloy et al. 2013: Figure 8), which highlights that the placement of this taxon should be treated with caution.

We also found Cratia gracilis and Kururubatrachus gondwanicus nested within Hyloidea. The latter was placed in a polytomy among Neobatrachia in its original description and was assigned to Hyloidea based on the presence of diagnostic features such as the distally expanded and flange-like transverse process of sacral vertebra, and anterior presacral vertebrae with elongate transverse processes (Agnolin et al. 2020). In this sense, our results confirm this assignment. As stated 
earlier, uncertainties are expected when dealing with the fossil record, especially given currently limited taxon sampling across the major lineages of Anura (Baéz et al. 2009, Agnolin et al. 2020).

Nevertheless, our results lend support to the notion that several hyloid lineages might have already been diversified in early Cretaceous times (Agnolin et al. 2020). This indicates that the origin and diversification of this clade were already in place at least around 120 Maa., well before the K/Pg boundary, contradicting molecular hypotheses that support a recent diversification of major frog clades triggered by the K/Pg mass extinction (e.g. Feng et al. 2017, Jetz \& Pyron 2018, Agnolin et al. 2020). However, an accurate picture of the evolutionary history of South American anurans is contingent on a more definitive answer to whether these fossils are stem-group or crown-group hyloids. To tackle this matter, besides a larger taxonomic sampling of major lineages of Anura (such as the early-diverging Rhinodermatidae, Hylodidae, and Alsodidae; Feng et al. 2017, Hime et al. 2020), a broader comparative osteological study of extant taxa is needed to develop a set of characters that could potentially be informative at large phylogenetic scales, as noted above.

Finally, the present description highlights the remarkable value of the Crato Formation as a Laggerstätte (Martill 2007). Regarding Anura, this geological deposit keeps standing out for harboring a highly diverse assemblage of fossil Neobatrachia, including some of the earliest known records for this group (Baéz et al. 2009). This is particularly important for macroevolutionary studies since the fossil record figures as the major source of evidence for the presence of a given clade at a past moment in geological history (Agnolin et al. 2020). Furthermore, we also call attention to the fact that a lot of work is still needed to refine the phylogenetic hypotheses for these fossil taxa. Thus, future investigations focused on uncovering new preserved specimens, as well as novel ways to analyze existing data and build a more comprehensive phylogenetic dataset, would contribute to more robust evolutionary inferences.

\section{Acknowledgments}

We thank Juliana de Moraes Leme Basso for providing the access to the specimen and the help during the visits in Department of Sedimentary and Enviromental Geology of the University of São Paulo. Pedro Moura acknowledges Coordenação de Aperfeiçoamento de Pessoal de Nivel Superior (CAPES) for financial support (process \#1769051).

\section{REFERENCES}

AGNARSSON I \& MILLER JA. 2008. IS ACCTRAN better than DELTRAN? Cladistics 24: 1-7.

AGNOLIN FA, CARVALHO IS, ROLANDO AMA, NOVAS FE, XAVIERNETO J, ANDRADE JAFG \& FREITAS FI. 2020. Early Cretaceous neobatrachian frog (Anura) from Brazil sheds light on the origin of modern anurans. J South Am Earth Sci 101: 102633.

BAÉZ AM \& GÓMES RO. 2018. Dealing with homoplasy: osteology and phylogenetic relationships of the bizarre neobatrachian frog Baurubatrachus pricei from the Upper Cretaceous of Brazil. J Syst Palaeontol 16(4): 279-308.

BÁEZ AM, MOURA GJB \& GÓMEZ RO. 2009. Anurans from the Lower Cretaceous Crato Formation of northeastern Brazil: implications for the early divergence of neobatrachians. Cretaceous Res 30: 829-846.

BÁEZ AM \& PERI S. 1989. Baurubatrachus pricei, nov. gen. et sp., un anuro del Cretácico Superior de Minas Gerais, Brasil. An Acad Bras Cienc 61: 447-458.

BLOTTO BL, PEREYRA MO, GRANT T \& FAIVOVICH J. 2020. Hand and Foot Musculature of Anura: Structure, Homology, Terminology, and Synapomorphies for Major Clades. Bull Am Mus Nat Hist 443: 1-156.

BREMER K. 1988. The limits of aminoacid sequence data in angiosperm phylogenetic reconstruction. Evolution 42: 795-803.

CARVALHO IS, AGNOLIN F, ROLANDO MAA, NOVAS FE, XAVIERNETO J, FREITAS FI \& ANDRADE JAFG. 2019. A new genus of 
pipimorph frog (Anura) from the early Cretaceous Crato formation. aptian. and the evolution of South American tongueless frogs. J South Am Earth Sci 9: 222-233.

CHEN J, BEVER GS, YI HY \& NORELL MA. 2016. A burrowing frog from the late Paleocene of Mongolia uncovers deep history of spadefoot toads (Pelobatoidea) in East Asia. Scientific Reports 6: 1-7.

FABREZI M. 1992. El carpo de los anuros. Alytes 10: 1-29.

FABREZI M. 2001. A survey of prepollex and prehallux variation in anuran limbs. Zool J Linnean Soc 131: 227-248.

FARRIS JS. 1969. A successive approximations approach to character weighting. Syst Biol 18: 374-385.

FARRIS JS. 1983. The logical basis of phylogenetic analysis. In: Platnick NI \& Funk VA (Eds), Advances in Cladistics II. Columbia University Press, New York, p. 7-36.

FENG YJ, BLACKBURN DC, LIANG D, HILLIS DM, WAKE DB, CANNATELLA DC \& ZHANG P. 2017. Phylogenomics reveals rapid, simultaneous diversification of three major clades of Gondwanan frogs at the Cretaceous-Paleogene boundary. Proc Natl Acad Sci USA: e5865.

FORD L \& CANNATELLA C. 1993. The major clades of frogs. Herpetol Monog 7: 94-117.

FROST DR ET AL. 2006. The amphibian tree of life. Bull Am Mus Nat Hist 297: 1-370.

FROST DR. 2020. Amphibian Species of the World: an Online Reference. Version 6.0. Accessed on September $12^{\text {th }}, 2020$. Electronic Database accessible at http:// research.amnh.org/herpetology/amphibia/index.html. American Museum of Natural History, New York, USA.

GAUPP E. 1896. Ecker's und Wiedersheim: Anatomie des frosches. Vol. 2. Friedrich Vieweg und Sohn, Braunschweg, $x i i i+227$ p.

GolobofF PA. 2003. Parsimony, likelihood, and simplicity. Cladistics 19: 91-103.

GOLOBOFF PA, FARRIS JS \& NIXON KC. 2008a. TNT: Tree analysis using New Technologies. Cladistics 24: 774-786.

GOLOBOFF PA, CARPENTER JM, ARIAS JS \& ESQUIVEL DRM. 2008b. Weighting against homoplasy improves phylogenetic analysis of morphological data sets. Cladistics 24: 1-16.

GOODMAN M, OLSON CB, BEEBER JE \& CZELUSNIAK J. 1982. New perspectives in the molecular biological analysis of mammalian phylogeny. Acta Zool Fen 169: 19-35.

GRANT T \& KLUGE AG. 2008. Credit where credit is due: the Goodman-Bremer support metric. Mol Phyl Evol 49: 405-406.
GRANT T \& KLUGE AG. 2009. Parsimony, explanatory power, and dynamic homology testing. System Biodiver 7(4): 357-363.

HIME PM ET AL. 2020. Phylogenomics reveals ancient gene tree discordance in the Amphibian Tree of Life. Syst Biol syaa034: 1-18.

INIESTO M, VILLALBA I, BUSCALIONI ÁD, GUERRERO MC \& LÓPEZARCHILLA AI. 2017. The effect of microbial mats in the decay of anurans with implications for understanding taphonomic processes in the fossil record. Sci Rep 7(45160): 1-12.

JETZ W \& PYRON RA. 2018. The interplay of past diversification and evolutionary isolation with present imperilment across the amphibian tree of life. Nature Ecol Evol 2: 850-858.

KELLNER AWA. 1994. Comments on the paleobiogeography of Cretaceous archosaurs during the opening of the South Atlantic Ocean. Acta Geol Leopold 39:615-625.

KELLNER AWA. 1996a. Reinterpretation of a remarkably well-preserved pterosaur soft tissue from the Early Cretaceous of Brazil. J Vertebr Paleontol 16: 718-722.

KELLNER AWA. 1996b. Fossilized theropod soft tissue. Nature 379: 32.

KLUGE AG. 1989. A Concern for Evidence and a Phylogenetic Hypothesis of Relationships Among Epicrates (Boidae, Serpentes). Syst Zool 38(l): 7-25.

KLUGE AG \& GRANT T. 2006. From conviction to antisuperfluity: old and new justifications of parsimony in phylogenetic inference. Cladistics 22: 276-288.

LALOY F, RAGE JC, EVANS SE, BOLSTEL R, LENOIR N \& LAURIN M. 2013. A Re-Interpretation of the Eocene Anuran Thaumastosaurus Based on MicroCT Examination of a 'Mummified' Specimen. PLOSOne 8(9): e74874.

LEAL MEC \& BRITO PM. 2006. Anura do Cretáceo Inferior da Bacia do Araripe, Nordeste do Brasil. In: Gallo V, Brito PM, Silva HMA \& Figueiredo FJ (Eds), Paleontología de Vertebrados. Grandes Temas e Contribuições Científicas. Interciencia, Rio de Janeiro, p. 145-152.

LEITE KJG, HESSEL MH \& NETO JAN. 2011. Importância e Limitação do Estudo dos Anuros Cretáceos. XXII Congresso Brasileiro de Paleontologia, p. 710-713.

LYNCH JD. 1971. Evolutionary relationships, osteology and zoogeography of leptodactyloid frogs. Misc publ Univ Kans Mus Nat Hist 53: 1-238.

LYNCH JD. 1973. The transition from archaic to advanced frogs. In: Vial JL (Ed), Evolutionary Biology of The Anurans. 
Contemporary Research on Major Problems. University of Missouri Press, Columbia, p. 133-182.

MADDISON WP \& MADDISON DR. 2018. Mesquite: a modular system for evolutionary analysis. Version 3.51, http:// mesquiteproject.org.

MARTILL DM. 1988. Preservation of fossil fish in the Cretaceous Santana Formation of Brazil. Paleontology 31: 1-18.

MARTILL DM. 1989. The Medusa effect: instantaneous fossilization. Geology Today 5: 201-205.

MARTILL DM. 2007. The age of the Cretaceous Santana Formation fossil Konservat Lagerstätte of northeast Brazil: a historical review and an appraisal of the biochronostratigraphic utility of its palaeobiota. cretaceous Res 28: 895-920.

MEDEIROS RA, PONTE FC \& PONTE FILHO FC. 2001. Análise estratigráfica da Bacia do Araripe: Parte 2-análise de facies. Coleção Chapada do Araripe. Crato, CE. Direção Nacional da Produção Mineral/URCA/Sociedade Brasileira de Paleontologia 1: 93-100.

MOURA GJB \& BARRETO AMF. 2006. Aspectos Tafonômicos da Anurofauna da Formação Crato, Eocretaceo da Bacia do Araripe, Nordeste do Brasil. Est Geol 16: 3-15.

PYRON RA. 2014. Biogeographic Analysis Reveals Ancient Continental Vicariance and Recent Oceanic Dispersal in Amphibians. Syst Biol 63: 779-797.

REIG OA. 1958. Proposiciones para una nueva macrosistemática de los anuros (nota preliminar). Physis 21: 109-118.

ROELANTS K, GOWER DJ, WILKINSON M, LOADER SP, BIJU SD, GUILLAUME K, MORIAU L \& BOSSUYT F. 2007. Global patterns of diversification in the history of modern amphibians. P Natl Acad Sci USA 104: 887-892.

TRUEB L. 1970. Evolutionary relationships of the casqueheaded tree frogs with coossified skulls. Family Hylidae. Univ Kans publ Mus Nat 18: 547-716.

TRUEB L. 1973. Bones, Frogs, and Evolution. In: Vial JL (Ed), Evolutionary Biology of the Anurans: Contemporary Research on Major Problems. University of Missouri Press, Columbia, p. 65-132.

TRUEB L. 1993. Patterns of Cranial Diversity Among the Lissamphibia. In: Hanken J \& Hall BK (Eds), Patterns of Structural and Systematic Diversity. University of Chicago Press, Chicago, p. 255-343.

VIANA MSSE \& NEUMANN VHML. 2002. Membro Crato da Formação Santana, Chapada do Araripe, CE. Sítios Geológicos e Paleontológicos do Brasil 2002: 113-120.

\section{How to cite}

MOURA PHAG, COSTA FR, ANELLI LE \& NUNES I. 2021. A new genus of fossil frog (Anura) from lower Cretaceous deposits in South America. An Acad Bras Cienc 93: e20191560. DOI 10.1590/0001-3765202120201560.

Manuscript received on October 2, 2020;

accepted for publication on February 20, 2021

PEDRO HENRIQUE A.G. MOURA ${ }^{1}$

https://orcid.org/0000-0003-3391-6149

\section{FABIANA R. COSTA ${ }^{2}$}

https://orcid.org/0000-0003-3596-0143

\section{LUIZ E. ANELLI ${ }^{3}$}

https://orcid.org/0000-0002-5228-9833

\section{IVAN NUNES ${ }^{1}$}

https://orcid.org/0000-0001-7985-2836

${ }^{1}$ Universidade Estadual Paulista Júlio de Mesquita Filho (UNESP), Laboratory of Herpetology, Institute of Biosciences, Campus do Litoral Paulista, Pça. Infante D. Henrique, s/n, Parque Bitaru, 11330-900 São Vicente, SP, Brazil

${ }^{2}$ Universidade Federal do ABC (UFABC), Laboratory of Vertebrate Paleontology and Animal Behavior (LAPC), Center of Natural and Human Sciences, Campus São Bernardo do Campo, Alameda da Universidade, s/n, Anchieta, 09606-045 São Bernardo do Campo, SP, Brazil

${ }^{3}$ Universidade de São Paulo (USP), Department of Sedimentary and Environmental Geology, Geosciences Institute, Rua do Lago, 562, Butantã, 05508-900 São Paulo, SP, Brazil

\section{Correspondence to: Fabiana Rodrigues Costa}

E-mail:fabiana.costa@ufabc.edu.br

\section{Author contributions}

Costa FR, Anelli LE, and Nunes I conceived the study. Moura PHAG, Costa FR, and Nunes I delimited the methods and analyses. Moura PHAG and Nunes I carried out the analyses and interpreted the results. All authors worked on the manuscript and contributed to the final version and revisions.

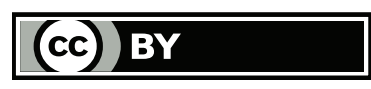

